\title{
Violence and mental disorders: a structured review of associations by individual diagnoses, risk factors, and risk assessment
}

Daniel Whiting, ${ }^{\mathrm{a}}$ Paul Lichtenstein ${ }^{\mathrm{b}}$ and Seena Fazel $\mathrm{a}^{\mathrm{a}^{*}}$

This is a submitted version of an article subsequently published:

Whiting D, Lichtenstein P, Fazel S. Violence and mental disorders: a structured review of associations by individual diagnoses, risk factors, and risk assessment. The Lancet Psychiatry. Published online October 20, 2020. DOI: https://doi.org/10.1016/S2215-0366(20)30262-5

\section{Affiliations}

${ }^{a}$ Department of Psychiatry, Warneford Hospital, University of Oxford, UK (Prof S. Fazel MD, D. Whiting BM BCh)

${ }^{\mathrm{b}}$ Department of Medical Epidemiology and Biostatistics, Karolinska Institutet, Stockholm, Sweden (Prof P. Lichtenstein PhD)

Correspondence to:

Prof Seena Fazel, Department of Psychiatry, Warneford Hospital, University of Oxford Oxford OX3 7JX, UK. seena.fazel@psych.ox.ac.uk 


\section{Summary}

In this review, we summarise evidence on the association between different mental disorders and violence with emphasis on high quality designs and replicated findings. Relative risks are typically increased for all violent outcomes in most diagnosed psychiatric disorders with elevated odds in the range of 2 to 4 after adjustment for familial and other sources of confounding. Absolute rates of violent crime over 5-10 years are typically below 5\% in people with mental illness, which increases to $6-10 \%$ in personality disorders and schizophrenia-spectrum disorders, and more than $10 \%$ in substance misuse. Past criminality and comorbid substance misuse are strongly predictive of future violence in many individual disorders. National clinical practice guidelines are reviewed, which vary in content and require updating to reflect the current epidemiological evidence. Standardised and clinically feasible approaches to the assessment and management of violence risk in general psychiatric settings need to be developed.

\section{Introduction}

Whether psychiatric disorders increase the risk of violence has been a key concern in mental health for decades. Although associations between serious mental illness and violence have long been identified, its precise nature has been the topic of considerable research, public health and policy debate. Its importance is underscored by the inclusion of violence risk as a key criterion for hospital detention in mental health laws and from public surveys suggesting that the perception of violence in people with psychiatric disorders increases stigma. Further from a public health perspective, violence is considered preventable, and healthcare interventions are among population approaches to reduce violence, crime, and victimization. ${ }^{1}$ 
In this review, we summarise evidence examining associations between individual psychiatric diagnoses and violent outcomes, with an emphasis on high quality methods, which may lead to improved assessment and management of violence and related risks. We have outlined national clinical practice guidelines on violence risk assessment and management and examine to what extent they incorporate this evidence. Throughout, we have focused on clinical diagnoses based on ICD and DSM, and interpersonal violence. Consequently, we have not considered verbal aggression, agitation, non-violent crimes, and other antisocial outcomes that have less public health importance. Furthermore, we have not included self-harm or suicide within our violence definition as they are distinct outcomes for interventions, services and guidelines. We have excluded intimate partner violence for similar reasons.

\section{Methods}

We searched PubMed, PsycINFO and Global Health for English language studies published between 27 March, 2009 and 6 April, 2020. Search terms included (violen* or homicid*) and synonyms for included psychiatric diagnoses, e.g. (bipolar or mania or manic*) supplemented with terms covering a broader category of any mental disorder (mental illness* or mental disorder* or psychiatric illness*/disorder* or psychiatric diagnosis/diagnoses). We preferentially included larger primary studies that compared violence rates in individuals with a specific diagnosis with general population or unaffected sibling controls, and systematic reviews. Although no formal quality assessment was undertaken, we only included studies with clear case definitions, outcome measurement and choice of comparison group. Highly cited reports published before 2009 were considered. Reference lists were not manually checked, nor was a meta-analysis considered due to clinical and methodological heterogeneity. 
We have highlighted studies that used officially registered violent outcomes (such as arrest or conviction). Self-report scales, whilst practical, are limited by recall bias, inter-rater variability and missing outcomes for those unable to participate, which may be a direct consequence of developing the outcome (e.g. incarceration following a violent offence) or exacerbation of their mental health problems. Register-based outcomes have clear strengths in relation to these potential biases, as do objective, clearly defined markers (e.g. incident reporting systems) not requiring patient contact. Another strength is that contact with the criminal justice system can be stressful and consume healthcare resources for assessment or follow-up, and hence is relevant for public health. Whilst conviction is the most robust measure, delays or diversions, or variations in how mental health outcomes are recorded, suggest that using arrest or charges can be considered as alternative outcomes, particularly where statistical power is limited or diversion from criminal justice is likely (e.g. in vulnerable or mentally disordered populations).

\section{Epidemiology of violence in mental disorders}

In this section, for each diagnostic category, we review relative risks and findings from sibling-control studies where possible (see Table 1 and Figure 1 for summary findings). We discuss the potential population impact of treatment, and report absolute risks (see Figure 2). Diagnoses are considered separately, however comorbidity is common ${ }^{2}$ and presence of additional disorders is associated with increased risk. ${ }^{3}$

\section{Schizophrenia}

Over 20 primary studies have shown increased violence risk in people with schizophreniaspectrum disorders compared with general population samples, including after adjustment for sociodemographic factors and substance misuse. A meta-analysis of studies from 11 highincome countries reported odds of violence ranging in men from 1 to 7 and in women from 4 
to $29 .{ }^{4}$ The association with homicide was stronger (pooled odds ratio [OR] 19.5, 95\% confidence interval $[\mathrm{CI}] 14 \cdot 7-25 \cdot 8$ ) although absolute lifetime risk of perpetration is very low $(0 \cdot 3 \%) .{ }^{4} \mathrm{~A}$ consistent finding is the mediating role of comorbid substance misuse, which typically doubles risk of violence, ${ }^{4}$ and may increase risk through multiple pathways, ${ }^{5}$ including substances increasing psychotic symptoms, self-medication with substances, and shared risk factors for psychosis and substance misuse. ${ }^{6}$ Studies using case registers have replicated these associations in Australia ${ }^{7}$ and Denmark. ${ }^{8}$ Temporal ordering of disorder onset and violent outcome in these new studies, rather than using lifetime diagnosis, has reported findings in a reanalysis of US national survey data that are consistent with register-based studies. ${ }^{3}$

Studies using unaffected sibling controls have provided more careful adjustment for residual confounding, including familial factors such as early environment and genetic liabilities (Figure 1). In one such study, 24,297 individuals with schizophrenia-spectrum disorders were matched to general population and sibling controls, ${ }^{9}$ with increased odds of violent crime in unaffected siblings versus general population controls of $1.8(95 \%$ CI 1.7-1.9) suggesting some familial confounding. The adjusted rate ratio for violent offending in patients versus their unaffected siblings was $4 \cdot 2$ (95\% CI 3.8-4.5). Importantly, sibling studies have been replicated in Israel ${ }^{10}$ and an updated investigation in Sweden, ${ }^{6}$ although these used lifetime crime outcomes.

Absolute rates of violence in schizophrenia indicate the relevance of prevention and management of risk to clinical services, particularly in those treating first episode. Over a lifetime, $23 \%$ of individuals with a schizophrenia diagnosis in Sweden had a violent conviction. ${ }^{6}$ Over three decades, around $13 \%$ of people had violent convictions following schizophrenia diagnosis. ${ }^{11}$ Using shorter time frames, five year incidence of violent conviction after first diagnosis was $11 \%$ in men and $3 \%$ in women. ${ }^{9}$ In first-episode 
psychosis, around 1 in 10 individuals perpetrated physical interpersonal violence in the 1-3 years after first contact with clinical services. ${ }^{12}$ Prior to first psychiatric contact, $12 \%$ of men subsequently diagnosed with a psychotic illness had violently offended in a Danish national register investigation, ${ }^{13}$ and other work has reported over half of patients with violent offending histories committed their first violent crime prior to illness onset, ${ }^{14}$ first psychiatric contact, ${ }^{15}$ or first diagnosis. ${ }^{16}$ In individuals with psychotic illnesses who commit homicide, around $40 \%$ do so during the first episode of illness prior to treatment initiation. ${ }^{17}$ Individuals with schizophrenia-spectrum disorders typically represent less than $10 \%$ of all homicide convictions, ${ }^{18-21}$ although a higher prevalence of $10-20 \%$ has also been found in studies incorporating information from forensic psychiatric evaluations. ${ }^{22,23}$ Studies typically exclude cases of murder-suicide, though where included, this will underestimate prevalence as it relies on prior contact with services to establish the presence of mental disorder. ${ }^{19}$

\section{Bipolar affective disorder}

One systematic review identified 9 studies conducted in 5 countries between 1990 and 2010, and reported increased odds for violence in bipolar disorder of between 2 and 9 and a pooled odds ratio of $4 \cdot 6\left(95 \%\right.$ CI 3.9-5.4) compared to the general population. ${ }^{24,25}$ Studies using register-linkage in Australia ${ }^{26}$ and survey data in the $\mathrm{US}^{3,27}$ have shown similar associations. Further, a study using Swedish population registers compared 15,337 individuals with bipolar disorder and 14,677 unaffected siblings separately to general population controls. ${ }^{28}$ Individuals with bipolar disorder had a five-fold increased risk of violence compared to the general population that was attenuated after adjustment for sociodemographic factors and

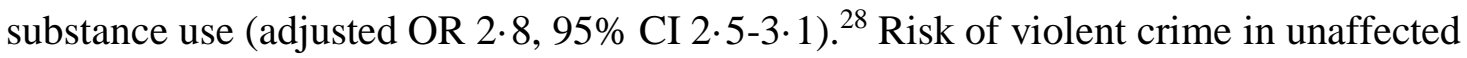
siblings (compared to the general population) was also increased, suggesting familial confounding (adjusted OR 1·2, 95\% CI 1·1-1.4). ${ }^{28}$ Absolute risks are less than in schizophrenia-spectrum disorders (Figure 2), partly due to different age and gender structure, 
with a higher proportion of younger men in schizophrenia-spectrum than bipolar disorders. Absolute rates of violent crime are estimated at $8 \%$ in men and $2 \%$ in women, of which $70 \%$ occur in the 5 years after diagnosis, ${ }^{28}$ and $11 \%$ when using a lifetime outcome. ${ }^{6}$

\section{Depression}

The relationship between depression and violence has not been researched to the same extent as suicide. One limitation of previous work has been the inclusion of selected groups with depression, such as inpatients, who may have been admitted to hospital due to violence risk. However, one investigation of 47,158 Swedish outpatients with depression reported a threefold increased risk of violent offending after diagnosis compared to the general population (adjusted OR 3·0, 95\% CI 2·8-3·3). ${ }^{29}$ This replicated findings from US household surveys ${ }^{3,27}$ and is consistent with longitudinal analyses of cohorts of adolescents and young adults in Holland, UK and Finland. ${ }^{30}$ The Swedish study also reported some familial confounding by examining siblings and twins. ${ }^{29}$ Over a follow-up of around 3 years after diagnosis, $3 \cdot 7 \%$ of men and $0.5 \%$ of women had violent convictions. When outcomes include informant and self-report, the MacArthur Risk Assessment study reported that $10 \%$ of patients with depression without substance use perpetrated violence in the 20 weeks following hospital discharge. ${ }^{31}$

\section{Attention deficit hyperactivity disorder (ADHD)}

A review of studies of individuals diagnosed with ADHD prior to 18 years of age identified 5 studies and increased odds of violence-related arrest of 3.6 (95\% CI 2.3-5.7) compared with controls without ADHD. ${ }^{32}$ An increased risk of incarceration, a proxy for violent offending, was also found, consistent with another review that reported a three-fold increased risk of

incarceration. ${ }^{33}$ Population surveys, although subject to limitations such as reliance on selfreport measures rather than diagnostic interview, have shown that associations between 
ADHD and violence are moderated by high psychiatric and substance comorbidity. ${ }^{34,35}$ In a longitudinal sibling design study of 1,366 children diagnosed with ADHD in Stockholm County, ${ }^{36}$ compared to population controls, odds of violent offending amongst cases remained significant at $2 \cdot 7(95 \%$ CI $2 \cdot 0-3 \cdot 8)$ after adjusting for socioeconomic factors, substance misuse, and comorbidity including conduct disorder. Unaffected siblings were also at a small increased risk versus population controls ${ }^{36}$ indicating familial confounding. In another register-based study, $15 \%$ of men and $4 \%$ of women with a diagnosis of ADHD were convicted of a violent offence during 4 years of follow-up. ${ }^{37}$

\section{Autism spectrum disorders}

Research examining the association between autism spectrum disorders (ASD) and risk of violence has consisted mostly of prevalence studies and case series, with previous reviews finding very limited evidence addressing relative risks. ${ }^{38,39}$ However, a longitudinal study of children in Stockholm compared 954 individuals with an ASD diagnosis with 9,540 population controls. ${ }^{36}$ A non-significant association with violent offending was found (OR $1 \cdot 3,95 \%$ CI $0 \cdot 9-2 \cdot 0)$, which was attenuated when adjusting for parental factors and comorbid substance misuse and conduct disorder (OR 1·1, 95\% CI 0.6-1.9). This study also included full- and half-siblings of cases, where there was no significant risk increase compared to matched controls. Another population-based study in Sweden included 5,739 individuals with ASD stratified by intellectual disability, hypothesising that this may modify offending through level of supervision and community access. ${ }^{40}$ However, violence risk was more related to comorbidity with ADHD or conduct disorder, present in $28 \%$ of all those diagnosed with ASD (which was two-thirds male). Risk was highest in those with ADHD/conduct disorder without ASD (relative risk $[\mathrm{RR}] 3 \cdot 9,95 \%$ CI 3.6-4.1), and the absolute rate of violent criminality in individuals with ASD (with or without comorbidities) was $4.4 \%$ (versus $2.6 \%$ in controls). 


\section{Personality disorders}

A meta-analysis pooled data from 10 studies in Europe and the US, totalling 9,578 individuals with personality disorder compared with 327,293 general population controls. ${ }^{41}$ Personality disorder was associated with a three-fold increased risk of violence (pooled OR $3 \cdot 0,95 \%$ CI $2 \cdot 6-3 \cdot 5)$, measured in included studies by either violent crime or self- and informant-report. Similar effects sizes were found in a Danish population report ${ }^{8}$ and a study of 49,398 Swedish men assessed at military conscription and followed up in national crime registers, ${ }^{42}$ although in the latter other and unspecified personality disorder was the largest subcategory.

Unsurprisingly, given that aggression and criminality from adolescence are included in DSM diagnostic criteria, antisocial personality disorder (ASPD) is the most important subcategory; a review reported $14 \%$ of individuals with ASPD had a violent outcome, and a substantially increased risk versus the general population (pooled OR 10·4, 95\% CI 7-3-14.0). ${ }^{41}$ ASPD is often considered separately to other personality disorders, such as in clinical guidelines in England (see Table 4 and Appendix 1). It should be noted that, although there is some overlap, psychopathy ${ }^{43}$ is a distinct construct, which has criteria, such as callousness, that overlap more with ICD dissocial personality disorder. Other work in personality disorder is cross-sectional, ${ }^{27}$ and has found links with ASPD, paranoid, narcissistic and obsessivecompulsive personality disorder, and, in men, increased risk in borderline personality disorder cannot be excluded, ${ }^{44}$ albeit limited by reliance on self-report for diagnosis and outcome. Other data suggested co-existing ASPD and psychiatric comorbidity contribute to violence risk in borderline personality disorder. ${ }^{45}$ In terms of absolute risks, $8 \%$ of individuals with a personality disorder diagnosis perpetrated a violent offence in up to 10 years of follow up in Swedish register data. ${ }^{46}$ 


\section{Post-traumatic stress disorder}

Studies examining the relationship between post-traumatic stress disorder (PTSD) and violence have focused on military populations and intimate partner violence. In a two-wave US survey, lifetime PTSD diagnosis in individuals with no history of military combat $(n=33,215)$ was not associated with violence between waves when controlling for alcohol use and anger after trauma. ${ }^{47}$ In military populations, using the proxy of combat exposure for PTSD, pooled data from 3 studies in the US and UK found an association with postdeployment aggression and violence (OR 3·2, 95\% CI 2·8-3·8). ${ }^{48}$ Having a combat role, ${ }^{49}$ rather than deployment alone, ${ }^{50}$ is associated with violent offending. Using register-based outcomes, in UK male soldiers deployed to Iraq and Afghanistan, PTSD remained associated with violent offending post-deployment when adjusted for sociodemographic and military service factors (adjusted hazard ratio $2 \cdot 2,95 \%$ CI $1 \cdot 4-3 \cdot 6),{ }^{49}$ and was also associated with offending after leaving service in this cohort. ${ }^{51}$ Associations between PTSD and violence has also been shown in a survey of UK Armed Forces reservists post-deployment. ${ }^{52}$ Similar to general population studies, alcohol use is an important comorbidity in military samples. ${ }^{53} \mathrm{In}$ terms of absolute risks, based on UK male military personnel with PTSD, it can be estimated that $9 \%$ violently offended up to 7 years post-deployment (compared with $3 \%$ of those without PTSD). ${ }^{49}$

\section{Substance misuse}

An umbrella review reported that substance misuse was the strongest risk factor for violence of psychiatric diagnoses (pooled OR 7·4, 95\% CI 4·3-12·7). ${ }^{54}$ The association holds across variations in outcome, substance type, and population. ${ }^{55}$ Substance misuse has been clearly linked to violent offending in Swedish longitudinal data on 292,420 males and 193,520 females, with hazard ratios (HR) of $16 \cdot 2$ for men (95\% CI $14 \cdot 6-17 \cdot 9)$ and $36 \cdot 0$ for women 
$\left(95 \%\right.$ CI 27.0-48 0). ${ }^{9}$ Significant associations have also been demonstrated in longitudinal data on male military conscripts in Sweden ${ }^{42}$ and a US household survey. ${ }^{3}$

For individual substances, evidence for independent associations with violence is more uncertain. A 2016 systematic review included 17 longitudinal studies of individual substances, most frequently marijuana, but findings were mixed and primary studies were mostly low quality. ${ }^{56}$ Studies such as of cannabis have often measured frequency of use, rather than disorder criteria. ${ }^{57,58}$ Systematic reviews of amphetamine, ${ }^{59}$ crack cocaine ${ }^{60}$ and opiate use ${ }^{61}$ have similarly been inconclusive, with substantial between-study heterogeneity and infrequent use of matched comparison groups, and isolating effects is further complicated by different formulations (e.g. crack versus powdered cocaine) ${ }^{62}$ A study of men who tested positive for anabolic steroids in Danish gyms compared with matched population controls found an association with incarceration, ${ }^{63}$ and a Swedish population survey of lifetime selfreported anabolic steroid use in men $(n=10,365)$ found increased odds of violent conviction after adjustment for other substances (OR 1·6, 95\% CI 0·8-3·3). ${ }^{64}$ Novel, high potency synthetic agents such as synthetic cannabinoids have been linked with agitation and violence, but common polysubstance use complicates interpretation. ${ }^{65}$ There is evidence that psychedelic drugs such as LSD and psilocybin may be an exception to the association with violence, ${ }^{66,67}$ although hallucinogen misuse in psychosis is associated with violence. ${ }^{5}$ Absolute risks are high - a recent study using Swedish population data showed $18 \%$ of individuals with a substance use disorder (made at any inpatient or outpatient specialist care episode) committed a violent offence during a mean follow-up of up to 10 years. ${ }^{46}$

\section{Alcohol use disorders}

Evidence for the association between alcohol use and violence is strong, despite overlaps with substance use. In an umbrella review, the overall pooled weighted effect size was 
significant (OR 2·0, 95\% CI 1·8-2.3 derived from reported effect size),${ }^{55}$ supporting longitudinal findings from Swedish population data (HR for violent offending in alcohol use disorders of $9 \cdot 0$ for men [95\% CI 8.2-9.9] and $19 \cdot 8$ for women [95\% CI 14.6-26.7]). ${ }^{9} \mathrm{~A}$ similar increased risk was found in 20 years of follow-up of a New Zealand birth cohort $(\mathrm{N}=1,265)$, where having 5 or more symptoms of alcohol misuse in the preceding year was associated with an incidence rate ratio for violent offending of $8 \cdot 0$ in men (95\% CI 6.4-10.1) and $15 \cdot 4$ in women $\left(95 \%\right.$ CI 11.4-20.8). ${ }^{68}$ In terms of absolute risks, Swedish population data showed $8 \%$ of individuals with a diagnosis of an alcohol use disorder committed a violent offence during a mean follow-up of up to 10 years. ${ }^{46}$

\section{Other psychiatric diagnoses}

There are fewer studies in other diagnostic groups, although recent investigations using family-based designs have been informative (Table 2). In eating disorders, there is little information. In anxiety disorders, a large Swedish longitudinal study using sibling controls however did find a significant association between anxiety disorders (excluding OCD and PTSD) and violent conviction. ${ }^{46}$ A systematic review has identified that risk in gambling disorder extends beyond acquisitive offending to violent offending, ${ }^{69}$ although case definition varies between studies. Conduct disorder contributes significantly to violence risk as a comorbidity in neurodevelopmental disorders,${ }^{40}$ and has been associated with violence in pooled data on violence-related arrest ${ }^{32}$ and a longitudinal study. ${ }^{70}$

\section{Risk in perspective}

Comparisons in absolute terms are important to contextualise risk estimates, including for the rare and most serious outcome of homicide, an event that can attract media coverage and contribute to stigmatizing views of mental illness. In the ten years 2006-2016, for example, there were 384 homicides in the UK committed by people with schizophrenia and delusional 
disorders $^{21}$ (equating to $6 \%$ of all homicides), an average of 35 per year, or around 0.06 per 100,000 general population (aged 10 and older) per year. The risk of stranger homicide is even rarer and has been estimated to be 1 in 14 million. ${ }^{71}$ In the same period, compared with other causes of death that may draw public attention, there were 23,393 road accident fatalities, ${ }^{72}$ an average of over 2,000 per year, or $3 \cdot 5$ per 100,000 total population per year. In the UK, there were an average of 29 people struck by lightning per year during 1988-2012, ${ }^{73}$ or around 0.05 per 100,000 , and two fatalities per year, or 0.003 per 100,000 .

\section{Risk factors in mental illness}

Clarifying risk factors within a diagnostic category can inform the understanding of mechanisms and potential interventions. This will assist in developing individualised assessments of risk, which can be linked to interventions to reduce risk. Several static (historical) and dynamic (time-varying and/or modifiable) risk factors have been identified (Table 3). Background criminal history factors, past violence and co-occurring substance use stand out as replicated strong risk factors..$^{74,75}$

\section{Genetic influences in the association between mental illness and violence}

When studying the causes and implications of the mental illness-violence associations reported above it is important to integrate the evidence from genetic research. First, antisocial behaviour is heritable (about 50\%). ${ }^{76}$ Second, childhood conduct disorder, which is partly heritable, is a predictor of violence later in life. ${ }^{70,77}$ Third, aggression, oppositional-defiant disorder and conduct disorder in childhood not only predicts violence but also other psychiatric outcomes - including most of the diagnoses discussed in this paper. ${ }^{70,77,78}$ Fourth, twin, ${ }^{70}$ sibling ${ }^{79}$ and molecular genetic studies ${ }^{80}$ have shown that to a considerable extent these childhood behaviours are associated with adult disorders due to a common genetic aetiology. Fifth, violence (similar to mental health problems) are highly polygenic; ${ }^{81}$ 
candidate genes for violent behaviour studies have not been replicated ${ }^{82}$ and even if some single genes and/or gene-by-environment interaction at some point will be evident, any such gene(s) will have a negligible impact on the mental illness-violence associations. Sixth, genetic factors associated with psychiatric disorders and violent convictions are also associated with subthreshold psychiatric symptoms throughout the general population. ${ }^{83,84}$ In other words, these traits are continuous phenotypes rather than the categorical entities currently defined in diagnostic manuals or by criminal convictions. Thus, genes do not code for specific behaviours or diagnoses, but rather they influence our tendency for emotions and thought processes, which can increase the likelihood for a criminal act. The next research challenge then is to try to delineate the biological pathways that are important in the complicated nexus between the actual genes and their products to the actual behaviour. Potential promising avenues could include callousness, impulsivity, emotional dysregulation, paranoia, and disinhibition, which are common to many diagnoses.

Nevertheless, until we have more understanding about the underlying mechanisms behind the psychiatric disorders and the association between them and violence, we should base decisions on prognosis on individual disorders, and use validated clinical prediction models; ${ }^{85}$ that is, for risk prediction we should continue to use the current diagnostic system, with the awareness that causal risk factors will lie in the consequences of gene products, and these will be the basis of novel biological and psychological interventions.

\section{Clinical practice guidelines}

We identified relevant guidelines from England, the United States and Australia and New Zealand and reviewed their content on the assessment or management of aggression, violence and risk to others (Table 4; references Supplement 1). Although violence was widely mentioned as a component of a general comprehensive risk assessment, there were 
inconsistencies, gaps, and varying detail on risk management. English guidelines for antisocial personality disorder were the only to recommend use of a violence risk assessment tool by specialist services (see Supplement 1), and others commented on the limitations of current tools in routine practice. Several outlined clinical factors to investigate during assessment, particularly comorbid substance misuse, and a past history of violence. High risk periods included the acute phase or first episode in schizophrenia. High or imminent risk to others should lead to close monitoring, and possible urgent referral to mental health services or hospital admission. Overall, there are considerable uncertainties in the guidelines on what constitutes the best approach to assessing violence risk, and on how to respond to any increased risks outside of acute illness. How these gaps are addressed should be considered when guidelines are revised.

\section{Implications for research and practice}

Important research gaps remain (Panel 1). For clinical practice, the reviewed evidence highlights violence as an adverse outcome relevant across psychiatric services. However, experience in assessing and managing violence risk typically sits within secure psychiatric (also known as forensic) services, who are only engaged when serious violent offending has already occurred. One way to translate epidemiological knowledge more readily into general clinical practice is the use of prediction models to support clinical judgement. By improving the consistency, accuracy, efficiency and transparency of risk assessment, clinically feasible assessment tools may in the future allow a more stratified approach to violence risk in psychiatry ${ }^{85}$ where interventions are targeted at those likely to derive the greatest absolute reduction in risk. While there may be overlapping aetiology to violence, risk prediction may work best in a diagnosis-specific manner. However, linkage to an intervention is necessary for any such tool to improve outcomes. To understand the potential clinical utility of such 
approaches, evaluations need to look further than single measures of predictive accuracy such as positive predictive value (which is the proportion of those identified as high risk of violence who go on to perpetrate violence), and consider a full range of metrics, anchored in discussion of the possible harms of misclassification when linked to a specific clinical decision for individual patients. ${ }^{86}$ Furthermore, tools need to consider the latest evidence on independent risk factors, rather than focusing solely on needs or expert opinion. Clinicians and researchers have too often focused on positive predictive values, which has obscured the potential of these tools to safely screen out low risk individuals to preserve resources (with high negative predictive values), or provide probability scores for risk (which is tested by how well it is calibrated, and how cardiovascular and cancer survival risk calculators are used in practice).

\section{Conclusion}

In this review, we have shown some individual psychiatric disorders, in particular, schizophrenia-spectrum, personality, and substance use disorders are clearly associated with elevated relative risks of violence. Better research designs and large-scale replications have led to more conservative estimates of this association. They have also shown that serious violence is rare amongst individuals with mental illness. Epidemiological work has allowed for modelling of the likely population impact of preventing violence perpetration in people with mental illness, and the consequences of prevention at an individual level for victims, patients, their carers, and clinical services. To enhance patient care, clinicians working in general psychiatric settings require clear practice guidelines for the assessment and management of violence risks beyond those related to behavioural disturbances during acute illness, which may be improved by using clinically feasible prediction models and tools. 


\section{Funding}

Dr Daniel Whiting is funded by a National Institute for Health Research (NIHR) Doctoral Research Fellowship for this research project. This publication presents independent research supported by the NIHR. The views expressed are those of the authors and not necessarily those of the National Health Service, the NIHR, or the Department of Health and Social Care. Professor Seena Fazel is funded by the Wellcome Trust. The funders had no role in the design of the review or writing of the report.

\section{Contributors}

SF and DW drafted the sections on epidemiology, risk in perspective, risk factors in mental illness, clinical practice guidelines and directions for future research. DW conducted the literature review, extracted the data, and prepared the tables and figures. PL drafted the section on genetic influences. All authors critically revised the manuscript.

\section{Declaration of interests}

All authors declare no competing interests. 
Panel 1. Directions for future research

- In bipolar disorder, prospective studies are needed to clarify the relationship between disease phase and violence risk.

- In depression, the effect of treatment is unknown and will require investigation of pooled RCT data or observational studies that account for confounding by indication.

- Personality disorder is a heterogeneous category, and a more trait-based approach to understanding associations with violence has been proposed. ${ }^{87}$

- Due to the considerable overlap between substance use disorders and with polysubstance misuse, new research should examine predominant classes or patterns of use and consider shared therapeutic targets. ${ }^{88}$

- Interventions targeting violence risk in psychiatric settings need to be developed. Transdiagnostic treatment targets may include comorbid substance misuse, impulsivity, and disinhibition, while other targets may be more disorder-specific, such as persecutory delusions in schizophrenia.

- Violence should be included among outcomes to test the effectiveness of psychiatric treatments, and future cohort studies and trials should routinely collect violent outcome data in an objective and standardised manner.

- Clinically feasible risk prediction tools should be examined for potential utility as a support to clinical decision-making. 
Table 1. Risk of violence in psychiatric disorders in meta-analyses, sibling-control studies and large primary general population control studies. 


\begin{tabular}{|c|c|c|c|c|}
\hline & Studies & $\begin{array}{c}\text { Systematic Review } \\
\text { Odd ratios }(95 \% \mathrm{Cls})^{*}\end{array}$ & $\begin{array}{c}\text { Sibling Study } \\
\text { Odds ratios ( } 95 \% \mathrm{Cls})\end{array}$ & $\begin{array}{l}\text { Population-based epidemiological study } \\
\text { Odds ratios ( } 95 \% \mathrm{Cls})\end{array}$ \\
\hline $\begin{array}{l}\text { Schizophrenia } \\
\text { and related } \\
\text { disorders }\end{array}$ & $\begin{array}{c}\text { Fazel }(2009)^{4} \\
\text { Fazel }(2014)^{9} \\
\text { Stevens }(2015)^{8}\end{array}$ & $\begin{array}{c}\mathbf{4 \cdot 0}(3 \cdot 0-5 \cdot 3) \text { male } \\
\mathbf{7 \cdot 9}(4 \cdot 0-15 \cdot 4) \text { female } \\
\text { ORs mostly not adjusted for socio- } \\
\text { economic factors. Males } k=13, n=9,379 \\
\text { cases; females } k=6, n=5,002 \text { cases. }\end{array}$ & $\begin{array}{c}\mathbf{7 \cdot 4}(7 \cdot 1-7 \cdot 8) \text { patient vs. population } \\
\mathbf{1 \cdot 8}(1 \cdot 7-1 \cdot 9) \text { sibling vs. population }{ }^{9} \\
\mathrm{n}=24,297 \text { cases; } 26,357 \text { unaffected siblings; } 485,940 \\
\text { population controls. Adjusted for sociodemographic } \\
\text { factors. }\end{array}$ & $\begin{array}{c}\mathbf{3 \cdot 0}(2 \cdot 7-3 \cdot 4) \text { male } \\
\mathbf{7 \cdot 5}(6 \cdot 0-9 \cdot 3) \text { female }^{8} \\
\mathrm{n}=471 \text { cases who violently offended; total population sample } \\
521,340 . \text { IRR adjusted for sociodemographic and psychiatric } \\
\text { factors. }\end{array}$ \\
\hline $\begin{array}{l}\text { Bipolar } \\
\text { disorder }\end{array}$ & $\begin{array}{l}\text { Fazel }(2010)^{25} \\
\text { Webb }(2014)^{28} \\
\text { Daff }(2014)^{26}\end{array}$ & $\begin{array}{l}4 \cdot 6(3 \cdot 9-5 \cdot 4)^{25} \\
\text { Unadjusted OR. } k=9 n=6,383 \text { cases; } \\
112,944 \text { controls. }\end{array}$ & $\begin{array}{c}\mathbf{2 \cdot 8}(2 \cdot 5-3 \cdot 1) \text { patient vs. population } \\
\mathbf{1 \cdot 2}(1 \cdot 1-1 \cdot 4) \text { sibling vs. population } 28 \\
\mathrm{n}=15,337 \text { cases; } 14,677 \text { unaffected siblings; } 306,740 \\
\text { population controls. RR adjusted for } \\
\text { sociodemographic and psychiatric factors. }\end{array}$ & $\begin{array}{c}\mathbf{3 \cdot 7}(2 \cdot 2-6 \cdot 0)^{26} \\
\mathrm{n}=1,076 \text { cases; } 4,813 \text { controls. Adjusted for demographic and } \\
\text { psychiatric factors. }\end{array}$ \\
\hline Depression & $\begin{array}{c}\text { Fazel }(2015)^{29} \\
\text { Van Dorn }(2012)^{3}\end{array}$ & No studies found. & $\begin{array}{c}\mathbf{2 \cdot 6}(2 \cdot 3-3 \cdot 0) \text { patient vs. population } \\
\mathbf{1 \cdot 4}(1 \cdot 2-1 \cdot 6) \text { sibling vs. population }{ }^{29} \\
\mathrm{n}=47,158 \text { cases; } 33,516 \text { unaffected siblings; } 898,454 \\
\text { population controls. Adjusted for sociodemographic } \\
\text { and psychiatric factors. } \\
\end{array}$ & $\begin{array}{l}\mathbf{2 \cdot 9}(2 \cdot 1-4 \cdot 0)^{3} \\
\text { Bivariate OR for depression without substance use. } \mathrm{n}=1,319 \\
\text { cases; } 24,951 \text { controls. }\end{array}$ \\
\hline ADHD & $\begin{array}{l}\text { Erskine }(2016)^{32} \\
\text { Lundstrom }(2014)^{36} \\
\text { Gonzalez }(2013)^{34}\end{array}$ & $\begin{array}{c}3 \cdot 6(2 \cdot 3-5 \cdot 7)^{32} \\
\text { OR for violence-related arrest. } k=5 \mathrm{n}=\text { not } \\
\text { reported. }\end{array}$ & $\begin{array}{c}\mathbf{2 \cdot 7}(2 \cdot 0-3 \cdot 8) \text { patient vs. population } \\
\mathbf{1 \cdot 3}(0 \cdot 9-2 \cdot 0) \text { sibling vs. population } \\
\text { (36 } \\
\mathrm{n}=1,366 \text { cases; } 898 \text { unaffected siblings; } 13,660 \\
\text { population controls. Adjusted for sociodemographic } \\
\text { and psychiatric factors. }\end{array}$ & $\begin{array}{c}1 \cdot 8(1 \cdot 1-2 \cdot 7)^{34} \\
\mathrm{n}=424 \text { cases; } 6,945 \text { controls. Adjusted for sociodemographic } \\
\text { and psychiatric factors. }\end{array}$ \\
\hline $\begin{array}{l}\text { Autism } \\
\text { spectrum } \\
\text { disorders }\end{array}$ & $\begin{array}{l}\text { King }(2014)^{38} \\
\text { Lundstrom }(2014)^{36} \\
\text { Heeramun }(2017)^{40}\end{array}$ & $\begin{array}{l}\text { No pooled ORs found. One review }{ }^{38} \text { found } \\
\text { only two studies with unbiased samples of } \\
\text { cases and controls. }\end{array}$ & $\begin{array}{c}\mathbf{1 . 1}(0.6-1 \cdot 9) \text { patient vs. population } \\
\mathbf{1 . 1}(0.6-2 \cdot 0) \text { sibling vs. population }{ }^{36} \\
n=954 \text { cases; } 661 \text { unaffected siblings; } 9,540 \\
\text { population controls. Adjusted for sociodemographic } \\
\text { and psychiatric factors. }\end{array}$ & $\begin{array}{l}1.0(0 \cdot 9-1 \cdot 1)^{40} \\
n=4,131 \text { cases; } 289,995 \text { general population controls. RR } \\
\text { adjusted for sociodemographic and psychiatric factors. }\end{array}$ \\
\hline $\begin{array}{l}\text { Personality } \\
\text { disorder }\end{array}$ & $\begin{array}{c}\text { Yu }(2012)^{41} \\
\text { Moberg }(2015)^{42}\end{array}$ & $\begin{array}{c}\mathbf{3 \cdot 0}(2 \cdot 6-3 \cdot 5)^{41} \\
\text { Fixed effects OR for all personality } \\
\text { disorders. } k=10 \mathrm{n}=9,578 \text { cases; } 327,293 \\
\text { controls. }\end{array}$ & No studies found. & $\begin{array}{l}\text { 2.7 }(2.2-3 \cdot 2)^{42} \\
\mathrm{n}=1,267 \text { cases; total population sample } 49,398 \text { (males). } \\
\text { Adjusted for sociodemographic and psychiatric factors. }\end{array}$ \\
\hline PTSD & $\begin{array}{l}\text { MacManus }(2015)^{48} \\
\text { MacManus }(2013)^{49}\end{array}$ & $\begin{array}{c}\mathbf{3 \cdot 2}(2 \cdot 8-3 \cdot 8)^{48} \\
\text { OR for post-combat exposure } \\
\text { aggression/violence in military personnel. } \\
k=3 n=13,203 \text {. }\end{array}$ & No studies found. & $\begin{array}{l}\mathbf{2 \cdot 2}(1 \cdot 4-3 \cdot 6)^{49} \\
\mathrm{n}=344 \text { cases; } 7,256 \text { controls. HR for post-military-deployment } \\
\text { violent offending adjusted for sociodemographic and military } \\
\text { service factors. }\end{array}$ \\
\hline
\end{tabular}




\begin{tabular}{|c|c|c|c|c|}
\hline $\begin{array}{l}\text { Substance } \\
\text { misuse }\end{array}$ & $\begin{array}{l}\text { Fazel }(2009)^{4} \\
\text { Fazel }(2014)^{9}\end{array}$ & $\begin{array}{l}\mathbf{7 \cdot 4}(4 \cdot 3-12 \cdot 7)^{4} \\
\text { OR for individuals with substance misuse } \\
\text { (including alcohol) without psychosis. } \\
\text { k=13. }\end{array}$ & No studies found. & $\begin{array}{c}\mathbf{1 6 \cdot 2}(14 \cdot 6-17 \cdot 9) \text { male } \\
\mathbf{3 6 \cdot 0}(27 \cdot 0-48 \cdot 0) \text { female } \\
\mathrm{n}=292,420 \text { men; } 193,520 \text { women general population controls } \\
\text { in total population study. HR adjusted for age. }\end{array}$ \\
\hline $\begin{array}{l}\text { Alcohol use } \\
\text { disorder }\end{array}$ & Fazel $(2014)^{9}$ & No studies found. & No studies found & $\begin{array}{c}\mathbf{9 \cdot 0}(8 \cdot 2-9 \cdot 9) \text { male } \\
\mathbf{1 9 \cdot 8}(14 \cdot 6-26 \cdot 7) \text { female }^{9} \\
\mathrm{n}=292,420 \text { men; } 193,520 \text { women general population controls } \\
\text { in total population study. HR adjusted for age. }\end{array}$ \\
\hline
\end{tabular}

*Pooled ORs report random effects meta-analysis unless otherwise stated.

ADHD: attention deficit hyperactivity disorder; Cl: confidence interval; IRR: incidence rate ratio; HR: hazard ratio; OR: odds ratio; PTSD: post-traumatic stress disorder; RR: relative risk. For each disorder, separate studies are referred to for each study category (systematic review, sibling control study and populationbased epidemiological study). Where more than one relevant study using an objective outcome measure was found for a category, we selected one study based on sample size. 
Table 2. Summary of recent primary studies that have examined violent outcomes in other diagnostic categories.

\begin{tabular}{|c|c|c|c|c|c|}
\hline Diagnosis & Study & Design & Population & Outcome & HR/OR/IRR (95\% Cl) \\
\hline Eating disorders & Yao $(2017)^{89}$ & $\begin{array}{l}\text { Longitudinal. } \\
\text { Register-based. }\end{array}$ & $\begin{array}{l}\mathrm{n}=957,106 \text { Swedish-born } \\
\text { females ( } 11,114 \text { with anorexia } \\
\text { nervosa, 5,197 with bulimia } \\
\text { nervosa). }\end{array}$ & Non-theft conviction. & $\begin{array}{l}\text { HR anorexia nervosa } 1 \cdot 2(1 \cdot 0-1 \cdot 3) \text {, } \\
\text { non-significant when accounting for } \\
\text { psychiatric comorbidities and } \\
\text { unmeasured familial factors. Bulimia } \\
\text { nervosa } 2 \cdot 2(1 \cdot 9-2 \cdot 5) \text {, attenuated but } \\
\text { significant when adjusted as above. }\end{array}$ \\
\hline \multirow[t]{2}{*}{ Anxiety disorders } & Sariaslan $(2020)^{46}$ & $\begin{array}{l}\text { Longitudinal. } \\
\text { Register-based. }\end{array}$ & $\begin{array}{l}\text { Swedish population, } \\
n=2,504,190 \text { without } \\
\text { psychiatric diagnosis, } 68,244 \\
\text { with anxiety disorder } \\
\text { diagnosis. }\end{array}$ & Violent conviction. & $\begin{array}{l}\text { HR } 2 \cdot 0(1 \cdot 7-2 \cdot 3) \text { using within-family } \\
\text { estimates comparing siblings, adjusted } \\
\text { for demographic, violence history and } \\
\text { psychiatric factors. }\end{array}$ \\
\hline & ten Have $(2014)^{90}$ & $\begin{array}{l}\text { Multi-wave } \\
\text { household } \\
\text { survey. Self- } \\
\text { report. }\end{array}$ & $\begin{array}{l}\mathrm{n}=5,303 \text { Dutch general } \\
\text { population ( } 539 \text { with any } \\
\text { anxiety disorder). }\end{array}$ & $\begin{array}{l}\text { Physical violence } \\
\text { (kicking, biting, hitting, } \\
\text { trying to wound) } \\
\text { between waves ( } 3 \\
\text { years). }\end{array}$ & $\begin{array}{l}\text { OR } 1 \cdot 8(0 \cdot 9-3 \cdot 5) \text { adjusted for } \\
\text { sociodemographic characteristics and } \\
\text { time at risk. }\end{array}$ \\
\hline $\begin{array}{l}\text { Obsessive- } \\
\text { compulsive } \\
\text { disorder }\end{array}$ & Lundstrom $(2014)^{36}$ & $\begin{array}{l}\text { Longitudinal. } \\
\text { Register-based. }\end{array}$ & $\begin{array}{l}\mathrm{n}=857 \text { children with OCD in } \\
\text { Stockholm, } 8,570 \text { general } \\
\text { population controls. }\end{array}$ & Violent conviction. & $\begin{array}{l}\text { OR } 0 \cdot 7(0 \cdot 3-1 \cdot 5) \text { adjusted for parental } \\
\text { factors and psychiatric comorbidity. }\end{array}$ \\
\hline \multirow[t]{2}{*}{$\begin{array}{l}\text { Intellectual } \\
\text { disability }\end{array}$} & Stevens $(2015)^{8}$ & $\begin{array}{l}\text { Longitudinal. } \\
\text { Register-based. }\end{array}$ & $\begin{array}{l}\mathrm{n}=521,340 \text { Danish population } \\
\text { ( } 42 \text { males and } 4 \text { females with } \\
\text { mental retardation who had } \\
\text { offended). }\end{array}$ & Violent conviction. & $\begin{array}{l}\text { IRR in males } 1 \cdot 7(1 \cdot 3-2 \cdot 3) \text { adjusted for } \\
\text { sociodemographic and psychiatric } \\
\text { factors, females insufficient cases. }\end{array}$ \\
\hline & Moberg $(2015)^{42}$ & $\begin{array}{l}\text { Longitudinal. } \\
\text { Register-based. }\end{array}$ & $\begin{array}{l}\mathrm{n}=49,398 \text { male Swedish } \\
\text { military conscripts ( } 524 \text { with } \\
\text { mental retardation). }\end{array}$ & Violent conviction. & $\begin{array}{l}\text { OR } 3 \cdot 6(2 \cdot 7-4 \cdot 8) \text { adjusted for personal } \\
\text { factors, upbringing conditions and } \\
\text { early behaviour. }\end{array}$ \\
\hline $\begin{array}{l}\text { Gambling } \\
\text { disorder }\end{array}$ & Laursen $(2016)^{91}$ & $\begin{array}{l}\text { Retrospective } \\
\text { cohort. Survey } \\
\text { and crime } \\
\text { register-based. }\end{array}$ & $\begin{array}{l}\mathrm{n}=18,625 \text { Danish population } \\
\text { ( } 384 \text { identified as problem } \\
\text { gamblers using lie/bet } \\
\text { questionnaire). }\end{array}$ & $\begin{array}{l}\text { Violent or sexual } \\
\text { charges in the } 6 \text {-year } \\
\text { periods prior to and }\end{array}$ & $\begin{array}{l}\text { OR } 2 \cdot 2(1 \cdot 1-4 \cdot 5) \text { adjusted for } \\
\text { sociodemographic factors, alcohol } \\
\text { consumption and smoking. }\end{array}$ \\
\hline
\end{tabular}




\begin{tabular}{|c|c|c|c|c|c|}
\hline & & & & $\begin{array}{l}\text { including the year of } \\
\text { two surveys. }\end{array}$ & \\
\hline Conduct disorder & Lichtenstein (2019) $^{70}$ & $\begin{array}{l}\text { Longitudinal. } \\
\text { Register-based. }\end{array}$ & $\begin{array}{l}\mathrm{n}=18,649 \text { Swedish twins, } \\
\text { conduct problems measured } \\
\text { with eight symptoms of } \\
\text { oppositional defiant disorder } \\
\text { conduct disorder in parent } \\
\text { interview aged } 9 \text { or } 11 \text { years. }\end{array}$ & $\begin{array}{l}\text { Violent criminality } \\
\text { aged } 17-22 .\end{array}$ & $\begin{array}{l}\text { When violent outcomes regressed on } \\
\text { continuous childhood conduct } \\
\text { problems HR females } 1 \cdot 4(1 \cdot 2-1 \cdot 5) \text {, } \\
\text { males } 1 \cdot 2(1 \cdot 2-1 \cdot 3) \text { adjusted for } \\
\text { parental socioeconomic status. HR for } \\
5-8 \text { conduct symptoms vs. } 0 \text { females } \\
4 \cdot 0(2 \cdot 2-7 \cdot 4) \text {, males } 3 \cdot 0(2 \cdot 2-4 \cdot 1) \text {. }\end{array}$ \\
\hline
\end{tabular}

$\mathrm{Cl}$ : confidence interval; HR: hazard ratio; IRR: incidence rate ratio; OCD: obsessive compulsive disorder; OR: odds ratio; PTSD: post-traumatic stress disorder. 
Figure 1. Relative risks of violence compared with general population controls from meta-analyses and longitudinal sibling-control studies.

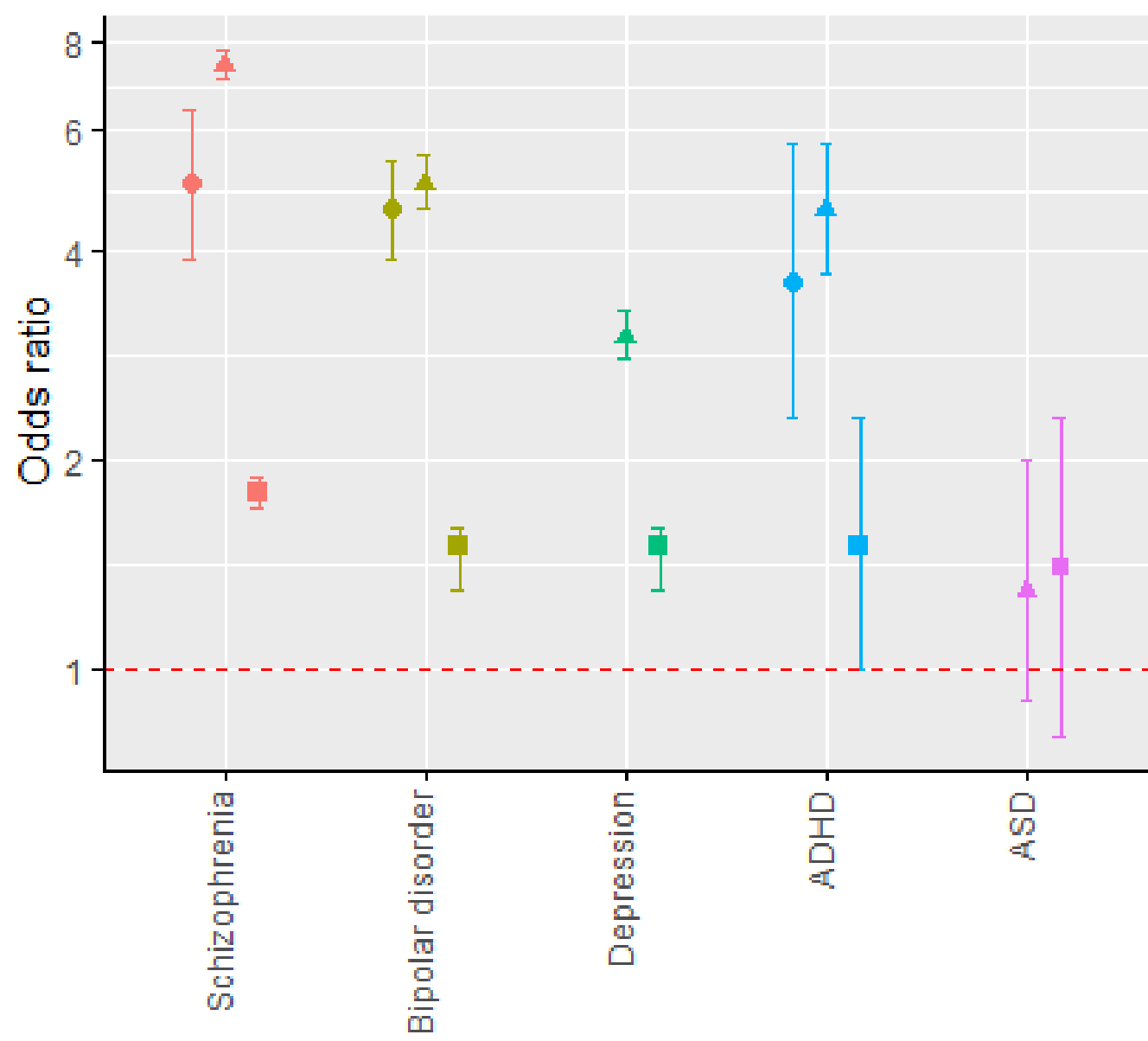

\section{Study}

- Meta-analysis of general population control studies

- Sibling control study - patients vs. controls

- Sibling control study - unaffected siblings vs. controls

ORs are presented with 95\% CI. Figures presented for comparison are without adjustment for substance use disorders or exclusion of individuals with substance misuse comorbidity. ADHD, attention deficit hyperactivity disorder; ASD, autism spectrum disorder. For references and study details see Table 1. 
Figure 2. Absolute risk (\%) of violent conviction in mental disorders according to different time periods.

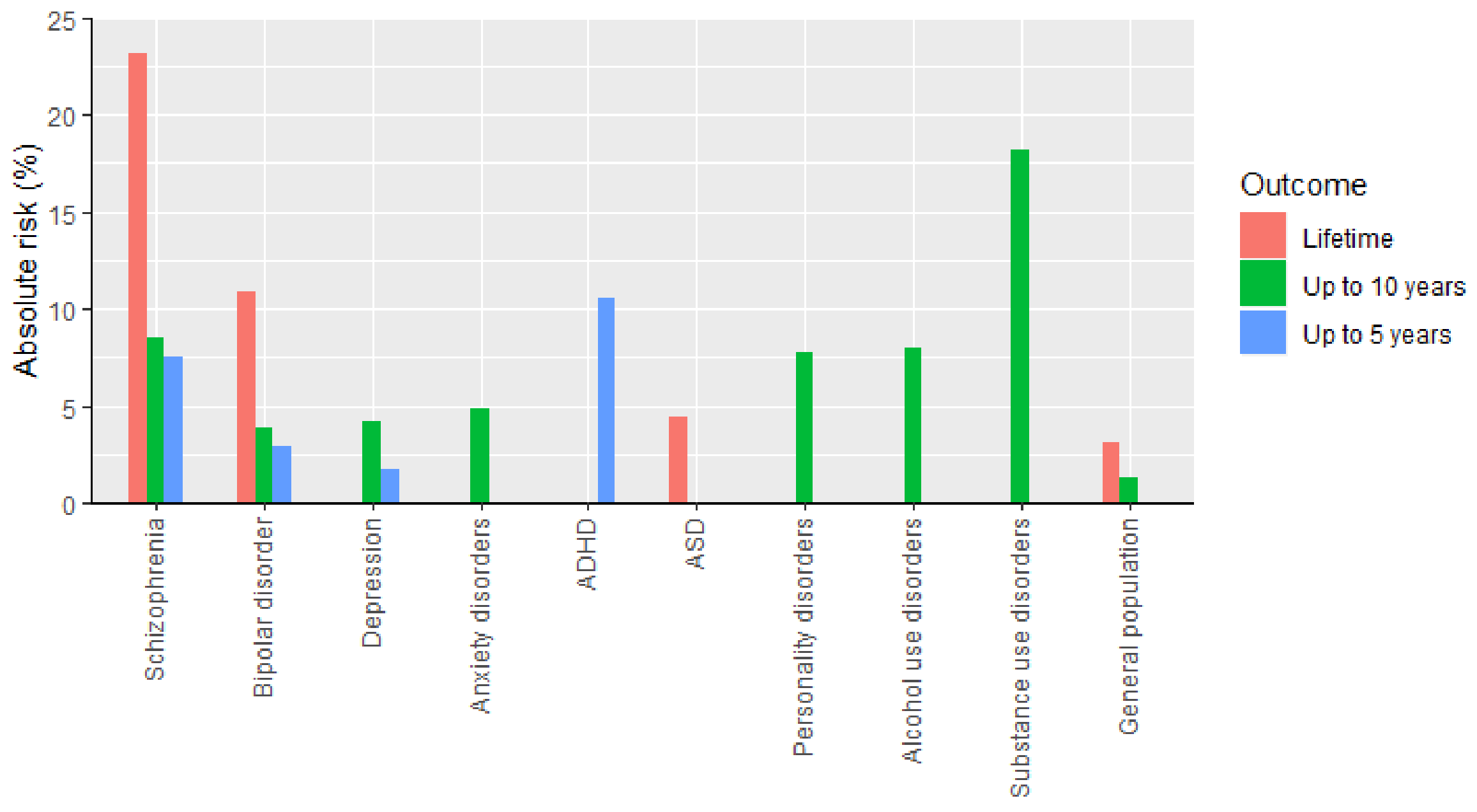

ADHD, attention deficit hyperactivity disorder; ASD, autism spectrum disorder. Figures presented for comparison are from primary studies using register-based violent conviction outcomes in Sweden. ${ }^{6,9,28,29,37,40,46}$ For general population, 2,425,703 people (lifetime) ${ }^{6}$ and 2,504,190 (up to 10 years) ${ }^{46}$ people were used in Sweden. Levels of violent assault ${ }^{92}$ and psychiatric morbidity ${ }^{93}$ have been shown to be similar in Sweden to other high-income countries. 
Table 3. Risk factors associated with violence in mental illness.

\begin{tabular}{|c|c|c|c|}
\hline & Risk Factor & Static & Dynamic \\
\hline \multirow[t]{3}{*}{ Sociodemographic } & Male gender ${ }^{28,85}$ & & \\
\hline & Low socio-economic status ${ }^{28,85}$ & & \\
\hline & Homelessness $^{75}$ & & \\
\hline \multirow[t]{3}{*}{ Criminal history } & Previous violent offence $28,29,75,85,94$ & & \\
\hline & Previous imprisonment ${ }^{75,94}$ & & \\
\hline & Previous non-violent offence ${ }^{28,75,94}$ & & \\
\hline \multirow[t]{2}{*}{ Family history } & Parent or sibling violent offence 85,94 & & \\
\hline & Parental substance use ${ }^{28,85}$ & & \\
\hline \multirow[t]{10}{*}{ Clinical factors } & Substance use $29,74,75,85$ & & \\
\hline & Victimisation $^{74,75}$ & & \\
\hline & Inpatient admission $28,29,85$ & & \\
\hline & Self-harm or suicide attempt ${ }^{28,29,74,75,85}$ & & \\
\hline & Hostility $^{75}$ & & \\
\hline & Impulsivity $^{75}$ & & \\
\hline & Lack of insight ${ }^{75}$ & & \\
\hline & Treatment non-adherence ${ }^{75}$ & & \\
\hline & Positive psychotic symptoms ${ }^{75}$ & & \\
\hline & Anger from persecutory beliefs ${ }^{95}$ & & \\
\hline
\end{tabular}

Based on studies of schizophrenia-spectrum disorders, bipolar disorder, and depression. 
Table 4. References to assessment and management of violence in clinical practice guidelines from the United States, England and Australia and New Zealand.

\begin{tabular}{|c|c|c|c|}
\hline & APA & NICE & RANZCP \\
\hline $\begin{array}{l}\text { Schizophrenia } \\
\text { and related } \\
\text { disorders }\end{array}$ & $\begin{array}{l}\text { Part of standard evaluation, highlights acute phase. } \\
\text { Details demographic and clinical risk factors (e.g. } \\
\text { distressing delusions, command hallucinations), suggests } \\
\text { e.g. consider admission, inform individuals at risk. }\end{array}$ & $\begin{array}{l}\text { Mentioned as a component of comprehensive } \\
\text { multidisciplinary assessment. Suggests crisis resolution, } \\
\text { signposts to guideline for acute agitation. }\end{array}$ & $\begin{array}{l}\text { Highlights first episode and comorbid } \\
\text { substances. Details clinical factors, routine } \\
\text { tools of low value, stresses continuity and } \\
\text { assertive substance disorder treatment. }\end{array}$ \\
\hline $\begin{array}{l}\text { Bipolar } \\
\text { disorder }\end{array}$ & $\begin{array}{l}\text { Ability to predict from clinical data limited. Suggests } \\
\text { close monitoring of patients with violent ideas; } \\
\text { substance use and psychosis increase risk. }\end{array}$ & $\begin{array}{l}\text { Mentioned as a component of general risk assessment. } \\
\text { Signposts to guideline for acute agitation. }\end{array}$ & $\begin{array}{l}\text { Noted association with alcohol/substances. No } \\
\text { further directions. }\end{array}$ \\
\hline Depression & $\begin{array}{l}\text { Higher risk if psychosis, impulsive, substances, past } \\
\text { aggression. Suggests assess violence history, ideation } \\
\text { and plans, close monitoring including safety of children. }\end{array}$ & $\begin{array}{l}\text { Not mentioned other than suggesting if immediate risk refer } \\
\text { urgently to mental health services. }\end{array}$ & Not mentioned. \\
\hline ADHD & $\begin{array}{l}\text { No adult guideline. No reference in equivalent paediatric } \\
\text { guidelines. }\end{array}$ & Not mentioned. & $\begin{array}{l}\text { Endorses NICE and Canadian ADHD resource } \\
\text { alliance guidelines. Not mentioned other than } \\
\text { suggesting consider anti-aggressive } \\
\text { medication if comorbid conduct disorder. }\end{array}$ \\
\hline $\begin{array}{l}\text { Autism } \\
\text { spectrum } \\
\text { disorders }\end{array}$ & $\begin{array}{l}\text { No adult guideline. AACAP practice parameters mention } \\
\text { physical aggression as one behavioural difficulty, } \\
\text { risperidone/aripiprazole approved for treatment. }\end{array}$ & $\begin{array}{l}\text { Harm to others mentioned as part of comprehensive } \\
\text { assessment, not further specified. }\end{array}$ & No guideline. \\
\hline $\begin{array}{l}\text { Borderline } \\
\text { personality } \\
\text { disorder }\end{array}$ & $\begin{array}{l}\text { In borderline personality disorder consider risk of angry/ } \\
\text { impulsive/violent behaviour; further assessment not } \\
\text { specified. Describes scenarios e.g. relationship crises, } \\
\text { care changes and strategies e.g. cognitive. }\end{array}$ & $\begin{array}{l}\text { Consider risk in borderline personality disorder in crisis; } \\
\text { assessment not specified. If high refer to mental health } \\
\text { services, consider child welfare, admission. }\end{array}$ & $\begin{array}{l}\text { Endorses Australian Government National } \\
\text { Health and Medical Research Council guideline } \\
\text { for borderline personality disorder. Not } \\
\text { mentioned. }\end{array}$ \\
\hline $\begin{array}{l}\text { Antisocial } \\
\text { personality } \\
\text { disorder }\end{array}$ & No guideline. & $\begin{array}{l}\text { Outlines stepped approach to risk assessment, refer to } \\
\text { forensic services if immediate risk or history of severe } \\
\text { violence, advises specialists use formal tools. Emphasis on } \\
\text { multi-agency care. Refers to role of CBT, treatment of } \\
\text { comorbidity including substance use, and hospital } \\
\text { admission. See supplement } 1 \text { for summary. }\end{array}$ & No guideline. \\
\hline $\begin{array}{l}\text { Conduct } \\
\text { disorder }\end{array}$ & $\begin{array}{l}\text { AACAP practice parameters; assess personal/family } \\
\text { history of violence. Comorbid substances predictive in } \\
\text { boys. Neuroleptics decrease aggression, side effects may } \\
\text { outweigh benefits. Imminent risk consider hospital. }\end{array}$ & $\begin{array}{l}\text { Aggression part of comprehensive assessment; if needed } \\
\text { develop risk management plan for harm to others. Consider } \\
\text { carefully monitored short-term risperidone for severe } \\
\text { aggression unresponsive to psychosocial intervention. }\end{array}$ & $\begin{array}{l}\text { No guideline, although importance of } \\
\text { addressing violence in CD highlighted in } \\
\text { document on cost effectiveness of early } \\
\text { intervention in mental illness. }\end{array}$ \\
\hline
\end{tabular}

Page 28 of 34 


\begin{tabular}{|c|c|c|c|}
\hline PTSD & $\begin{array}{l}\text { Comment on basis for potentially heightened } \\
\text { aggression, further assessment not specified. Suggests } \\
\text { general monitoring and e.g. treating substance use. }\end{array}$ & $\begin{array}{l}\text { Not mentioned other than recommending that if high risk } \\
\text { (self/others) concentrate on this risk first. }\end{array}$ & $\begin{array}{l}\text { Endorses various guidelines including NICE and } \\
\text { APA. }\end{array}$ \\
\hline $\begin{array}{l}\text { Substance } \\
\text { misuse }\end{array}$ & $\begin{array}{l}\text { Highlights risk scenarios with various substances and } \\
\text { intoxication/withdrawal states. Suggest assess for } \\
\text { homicidal thoughts and screen for domestic violence. }\end{array}$ & $\begin{array}{l}\text { Generally asses risk behaviour including domestic violence; } \\
\text { assessment not further specified. }\end{array}$ & $\begin{array}{l}\text { No guideline, although relevance to violence } \\
\text { noted in alcohol and illicit drugs policy } \\
\text { documents. }\end{array}$ \\
\hline
\end{tabular}

AAP, American Academy of Pediatrics; ADHD, attention deficit hyperactivity disorder; APA, American Psychiatric Association; NICE, National Institute for Health and Care Excellence; PTSD, post-traumatic stress disorder; RANZCP, Royal Australian and New Zealand College of Psychiatrists. APA guidelines are available at https://psychiatryonline.org/guidelines; NICE at https://www.nice.org.uk/guidance; RANZCP at https://www.ranzcp.org/practiceeducation/guidelines-and-resources-for-practice. For individual references, see Supplement 1. 


\section{References}

1. World Health Organization. Global status report on violence prevention 2014. Geneva: World Health Organization.

2. Caspi A, Houts RM, Belsky DW, Goldman-Mellor SJ, Harrington H, Israel S, et al. The $\mathrm{p}$ factor: one general psychopathology factor in the structure of psychiatric disorders? Clin Psychol Sci 2014; 2(2): 119-37.

3. Van Dorn R, Volavka J, Johnson N. Mental disorder and violence: is there a relationship beyond substance use? Soc Psychiatry Psychiatr Epidemiol 2012; 47(3): 487-503.

4. Fazel S, Gulati G, Linsell L, Geddes JR, Grann M. Schizophrenia and violence: systematic review and meta-analysis. PLoS Med 2009; 6(8): e1000120.

5. Lamsma J, Cahn W, Fazel S. Use of illicit substances and violent behaviour in psychotic disorders: two nationwide case-control studies and meta-analyses. Psychol Med 2019: 1-6.

6. Sariaslan A, Larsson H, Fazel S. Genetic and environmental determinants of violence risk in psychotic disorders: a multivariate quantitative genetic study of 1.8 million Swedish twins and siblings. Mol Psychiatry 2016; 21(9): 1251-6.

7. Short T, Thomas S, Mullen P, Ogloff J. Comparing violence in schizophrenia patients with and without comorbid substance-use disorders to community controls. Acta Psychiatrica Scandinavica 2013; 128(4): 306-13.

8. Stevens H, Laursen TM, Mortensen PB, Agerbo E, Dean K. Post-illness-onset risk of offending across the full spectrum of psychiatric disorders. Psychol Med 2015; 45(11): 2447-57.

9. Fazel S, Wolf A, Palm C, Lichtenstein P. Violent crime, suicide, and premature mortality in patients with schizophrenia and related disorders: a 38-year total population study in Sweden. Lancet Psychiatry 2014; 1(1): 44-54.

10. Fleischman A, Werbeloff N, Yoffe R, Davidson M, Weiser M. Schizophrenia and violent crime: a population-based study. Psychol Med 2014; 44(14): 3051-7.

11. Fazel S, Långström N, Hjern A, Grann M, Lichtenstein P. Schizophrenia, substance abuse, and violent crime. JAMA 2009; 301(19): 2016-23.

12. Winsper C, Ganapathy R, Marwaha S, Large M, Birchwood M, Singh SP. A systematic review and meta-regression analysis of aggression during the first episode of psychosis. Acta psychiatrica Scandinavica 2013; 128(6): 413-21.

13. Stevens H, Agerbo E, Dean K, Nordentoft M, Nielsen PR, Mortensen PB. Offending prior to first psychiatric contact: a population-based register study. Psychol Med 2012; 42(12): 2673-84.

14. Kooyman I, Walsh E, Stevens H, Burns T, Tyrer P, Tattan T, et al. Criminal offending before and after the onset of psychosis: examination of an offender typology. Schizophr Res 2012; 140(1-3): 198-203.

15. Munkner R, Haastrup S, Joergensen T, Kramp P. The temporal relationship between schizophrenia and crime. Soc Psychiatry Psychiatr Epidemiol 2003; 38(7): 347-53.

16. Hachtel $\mathrm{H}$, Harries $\mathrm{C}$, Luebbers $\mathrm{S}$, Ogloff JR. Violent offending in schizophrenia spectrum disorders preceding and following diagnosis. Aust N Z J Psychiatry 2018; 52(8): 782-92.

17. Nielssen $\mathrm{O}$, Large M. Rates of homicide during the first episode of psychosis and after treatment: a systematic review and meta-analysis. Schizophr Bull 2010; 36(4): 702-12.

18. Taylor PJ, Kalebic N. Psychosis and homicide. Curr Opin Psychiatry 2018; 31(3): 223-30.

19. Bennett D, Ogloff J, Mullen P, Thomas S, Wallace C, Short T. Schizophrenia disorders, substance abuse and prior offending in a sequential series of 435 homicides. Acta Psychiatrica Scandinavica 2011; 124(3): 226-33.

20. Penney SR, Prosser A, Grimbos T, Darby P, Simpson AIF. Time trends in homicide and mental illness in Ontario from 1987 to 2012: examining the effects of mental health service provision. Can J Psychiatry 2018; 63(6): 387-94.

21. The National Confidential Inquiry into Suicide and Safety in Mental Health. Annual Report: England NI, Scotland, Wales. October 2018. University of Manchester. 
22. Fazel S, Grann M. Psychiatric morbidity among homicide offenders: a Swedish population study. Am J Psychiatry 2004; 161(11): 2129-31.

23. Sturup J, Lindqvist P. Psychosis and homicide in Sweden - a time trend analysis 1987-2006. Int J Forensic Ment Health 2014; 13(1): 1-7.

24. Fazel S, Lichtenstein P, Grann M, Goodwin GM, Langstrom N. Bipolar disorder and violent crime: new evidence from population-based longitudinal studies and systematic review. Arch Gen Psychiatry 2010; 67(9): 931-8.

25. Fazel S, Lichtenstein P, Frisell T, Grann M, Goodwin G, Langstrom N. Bipolar disorder and violent crime: time at risk reanalysis. Arch Gen Psychiatry 2010; 67(12): 1325-6.

26. Daff $E$, Thomas SD. Bipolar disorder and criminal offending: a data linkage study. Soc Psychiatry Psychiatr Epidemiol 2014; 49(12): 1985-91.

27. Schwartz JA, Beaver KM, Barnes J. The association between mental health and violence among a nationally representative sample of college students from the United States. PLOS ONE 2015; 10(10): e0138914.

28. Webb RT, Lichtenstein P, Larsson H, Geddes JR, Fazel S. Suicide, hospital-presenting suicide attempts, and criminality in bipolar disorder: examination of risk for multiple adverse outcomes. $J$ Clin Psychiatry 2014; 75(8): e809-16.

29. Fazel S, Wolf A, Chang Z, Larsson H, Goodwin GM, Lichtenstein P. Depression and violence: a Swedish population study. Lancet Psychiatry 2015; 2(3): 224-32.

30. Yu R, Aaltonen M, Branje S, Ristikari T, Meeus W, Salmela-Aro K, et al. Depression and violence in adolescence and young adults: findings from three longitudinal cohorts. J Am Acad Child Adolesc Psychiatry 2017; 56(8): 652-8.

31. Monahan J. Reducing violence risk: diagnostically based clues from the MacArthur Violent Risk Assessment Study. In: Hodgins S. Effective prevention of crime and violence among the mentally ill. Amsterdam: Kluwer; 2000. p. 19-34.

32. Erskine HE, Norman RE, Ferrari AJ, Chan GC, Copeland WE, Whiteford HA, et al. Long-term outcomes of attention-deficit/hyperactivity disorder and conduct disorder: a systematic review and meta-analysis. J Am Acad Child Adolesc Psychiatry 2016; 55(10): 841-50.

33. Mohr-Jensen C, Steinhausen HC. A meta-analysis and systematic review of the risks associated with childhood attention-deficit hyperactivity disorder on long-term outcome of arrests, convictions, and incarcerations. Clin Psychol Rev 2016; 48: 32-42.

34. Gonzalez RA, Kallis C, Coid JW. Adult attention deficit hyperactivity disorder and violence in the population of England: does comorbidity matter? PLoS One 2013; 8(9): e75575.

35. Gudjonsson GH, Sigurdsson JF, Sigfusdottir ID, Young S. A national epidemiological study of offending and its relationship with ADHD symptoms and associated risk factors. J Atten Disord 2014; 18(1): 3-13.

36. Lundstrom S, Forsman M, Larsson H, Kerekes N, Serlachius E, Langstrom N, et al. Childhood neurodevelopmental disorders and violent criminality: a sibling control study. J Autism Dev Disord 2014; 44(11): 2707-16.

37. Lichtenstein P, Halldner L, Zetterqvist J, Sjolander A, Serlachius E, Fazel S, et al. Medication for attention deficit-hyperactivity disorder and criminality. N Engl J Med 2012; 367(21): 2006-14.

38. King C, Murphy GH. A systematic review of people with autism spectrum disorder and the criminal justice system. J Autism Dev Disord 2014; 44(11): 2717-33.

39. Im DS. Template to perpetrate: an update on violence in autism spectrum disorder. Harv Rev Psychiatry 2016; 24(1): 14-35.

40. Heeramun R, Magnusson C, Gumpert CH, Granath S, Lundberg M, Dalman C, et al. Autism and convictions for violent crimes: population-based cohort study in Sweden. J Am Acad Child Adolesc Psychiatry 2017; 56(6): 491-7.

41. Yu R, Geddes JR, Fazel S. Personality disorders, violence, and antisocial behavior: a systematic review and meta-regression analysis. J Pers Disord 2012; 26(5): 775-92. 
42. Moberg T, Stenbacka M, Tengstrom A, Jonsson EG, Nordstrom P, Jokinen J. Psychiatric and neurological disorders in late adolescence and risk of convictions for violent crime in men. $B M C$ Psychiatry 2015; 15: 299.

43. DeLisi M. Psychopathy as Unified Theory of Crime: Palgrave Macmillan, New York; 2016.

44. Coid JW, Gonzalez R, Igoumenou A, Zhang T, Yang M, Bebbington P. Personality disorder and violence in the national household population of Britain. J Forens Psychiatry Psychol 2017; 28(5): 620-38.

45. Gonzalez RA, Igoumenou A, Kallis C, Coid JW. Borderline personality disorder and violence in the UK population: categorical and dimensional trait assessment. BMC Psychiatry 2016; 16: 180.

46. Sariaslan A, Arseneault L, Larsson H, Lichtenstein P, Fazel S. Risk of subjection to violence and perpetration of violence in persons with psychiatric disorders in Sweden. JAMA Psychiatry 2020; 77(4): 359-67.

47. Blakey SM, Love H, Lindquist L, Beckham JC, Elbogen EB. Disentangling the link between posttraumatic stress disorder and violent behavior: Findings from a nationally representative sample. J Consult Clin Psychol 2018; 86(2): 169-78.

48. MacManus D, Rona R, Dickson H, Somaini G, Fear N, Wessely S. Aggressive and violent behavior among military personnel deployed to Iraq and Afghanistan: prevalence and link with deployment and combat exposure. Epidemiol Rev 2015; 37: 196-212.

49. Macmanus D, Dean K, Jones M, Rona RJ, Greenberg N, Hull L, et al. Violent offending by UK military personnel deployed to Iraq and Afghanistan: a data linkage cohort study. Lancet 2013; 381(9870): 907-17.

50. Pethrus CM, Frisell T, Reutfors J, Johansson K, Neovius K, Soderling JK, et al. Violent crime among Swedish military veterans after deployment to Afghanistan: a population-based matched cohort study. Int J Epidemiol 2019; 48(5): 1604-13.

51. MacManus D, Dickson H, Short R, Burdett H, Kwan J, Jones M, et al. Risk and protective factors for offending among UK Armed Forces personnel after they leave service: a data linkage study. Psychol Med 2019: 1-8.

52. Kwan J, Jones M, Hull L, Wessely S, Fear N, MacManus D. Violent behavior among military reservists. Aggress Behav 2017; 43(3): 273-80.

53. Elbogen EB, Johnson SC, Wagner HR, Sullivan C, Taft CT, Beckham JC. Violent behaviour and post-traumatic stress disorder in US Iraq and Afghanistan veterans. Br J Psychiatry 2014; 204(5): 368-75.

54. Fazel S, Smith EN, Chang Z, Geddes JR. Risk factors for interpersonal violence: an umbrella review of meta-analyses. Br J Psychiatry 2018; 213(4): 609-14.

55. Duke AA, Smith KM, Oberleitner LM, Westphal A, McKee SA. Alcohol, drugs, and violence: A meta-meta-analysis. Psychology of Violence 2018; 8(2): 238-49.

56. McGinty EE, Choksy S, Wintemute GJ. The relationship between controlled substances and violence. Epidemiologic Reviews 2016; 38(1): 5-31.

57. Lim JY, Lui CK. Longitudinal associations between substance use and violence in adolescence through adulthood. J Soc Work Pract Addict 2016; 16(1-2): 72-92.

58. Scholes-Balog KE, Hemphill SA, Evans-Whipp TJ, Toumbourou JW, Patton GC. Developmental trajectories of adolescent cannabis use and their relationship to young adult social and behavioural adjustment: A longitudinal study of Australian youth. Addict Behav 2016; 53: 11-8.

59. McKetin R, Leung J, Stockings E, Huo Y, Foulds J, Lappin JM, et al. Mental health outcomes associated with of the use of amphetamines: a systematic review and meta-analysis.

EClinicalMedicine 2019; 16: 81-97.

60. Butler AJ, Rehm J, Fischer B. Health outcomes associated with crack-cocaine use: systematic review and meta-analyses. Drug and Alcohol Dependence 2017; 180: 401-16.

61. Hayhurst KP, Pierce M, Hickman M, Seddon T, Dunn G, Keane J, et al. Pathways through opiate use and offending: a systematic review. Int J Drug Policy 2017; 39: 1-13. 
62. Vaughn MG, Fu QA, Perron BE, Bohnert ASB, Howard MO. Is crack cocaine use associated with greater violence than powdered cocaine use? Results from a national sample. Am J Drug Alcohol Abuse 2010; 36(4): 181-6.

63. Christoffersen T, Andersen JT, Dalhoff KP, Horwitz H. Anabolic-androgenic steroids and the risk of imprisonment. Drug Alcohol Depend 2019; 203: 92-97.

64. Lundholm L, Frisell T, Lichtenstein P, Langstrom N. Anabolic androgenic steroids and violent offending: confounding by polysubstance abuse among 10,365 general population men. Addiction 2015; 110(1): 100-8.

65. Clayton HB, Lowry R, Ashley C, Wolkin A, Grant AM. Health risk behaviors with synthetic cannabinoids versus marijuana. Pediatrics 2017; 139(4): 1-10.

66. Hendricks PS, Crawford MS, Cropsey KL, Copes H, Sweat N, Walsh Z, et al. The relationships of classic psychedelic use with criminal behavior in the United States adult population. $J$

Psychopharmacol 2018; 32(1): 37-48.

67. Thiessen MS, Walsh Z, Bird BM, Lafrance A. Psychedelic use and intimate partner violence:

The role of emotion regulation. J Psychopharmacol 2018; 32(7): 749-55.

68. Boden JM, Fergusson DM, Horwood L. Alcohol misuse and violent behavior: findings from a 30-year longitudinal study. Drug Alcohol Depend 2012; 122(1-2): 135-41.

69. Adolphe A, Khatib L, van Golde C, Gainsbury SM, Blaszczynski A. Crime and Gambling Disorders: A Systematic Review. J Gamb/ Stud 2019; 35(2): 395-414.

70. Lichtenstein P, Cederlöf $M$, Lundström S, D'Onofrio BM, Anckarsäter H, Larsson $H$, et al. Associations between conduct problems in childhood and adverse outcomes in emerging adulthood: a longitudinal Swedish nationwide twin cohort. J Child Psychol Psychiatry 2019; published online December 18. DOI: 10.1111/jcpp.13169.

71. Nielssen O, Bourget D, Laajasalo T, Liem M, Labelle A, Hakkanen-Nyholm H, et al. Homicide of strangers by people with a psychotic illness. Schizophr Bull 2011; 37(3): 572-9.

72. Department for Transport. Road accidents. https://roadtraffic.dft.gov.uk/customdownloads/road-accidents (accessed Feb 24, 2020).

73. Elsom DM, Webb JDC. Deaths and injuries from lightning in the UK, 1988-2012. Weather 2014; 69(8): 221-6.

74. Sariaslan A, Lichtenstein $\mathrm{P}$, Larsson $\mathrm{H}$, Fazel S. Triggers for violent criminality in patients with psychotic disorders. JAMA Psychiatry 2016; 73(8): 796-803.

75. Witt K, Dorn Rv, Fazel S. Risk factors for violence in psychosis: systematic review and metaregression analysis of 110 studies. PLOS ONE 2013; 8(2).

76. Gard AM, Dotterer HL, Hyde LW. Genetic influences on antisocial behavior: recent advances and future directions. Curr Opin Psychol 2019; 27: 46-55.

77. Fergusson DM, John Horwood L, Ridder EM. Show me the child at seven: the consequences of conduct problems in childhood for psychosocial functioning in adulthood. Journal of Child Psychology and Psychiatry 2005; 46(8): 837-49.

78. Kim-Cohen J, Caspi A, Moffitt TE, Harrington H, Milne BJ, Poulton R. Prior juvenile diagnoses in adults with mental disorder: developmental follow-back of a prospective-longitudinal cohort. Arch Gen Psychiatry 2003; 60(7): 709-17.

79. Pettersson E, Larsson H, Lichtenstein P. Common psychiatric disorders share the same genetic origin: a multivariate sibling study of the Swedish population. Mol Psychiatry 2016; 21(5): 717-21.

80. Ip HF, van der Laan CM, Brikell I, Sánchez-Mora C, Nolte IM, St Pourcain B, et al. Genetic association study of childhood aggression across raters, instruments and age. bioRxiv 2019: 854927.

81. Tielbeek JJ, Johansson A, Polderman TJC, Rautiainen M-R, Jansen P, Taylor M, et al. Genomewide association studies of a broad spectrum of antisocial behavior. JAMA psychiatry 2017; 74(12): 1242-50.

82. Vassos E, Collier DA, Fazel S. Systematic meta-analyses and field synopsis of genetic association studies of violence and aggression. Mol Psychiatry 2014; 19(4): 471-7. 
83. Taylor MJ, Martin J, Lu Y, Brikell I, Lundstrom S, Larsson H, et al. Association of genetic risk factors for psychiatric disorders and traits of these disorders in a Swedish population twin sample. JAMA Psychiatry 2019; 76(3): 280-9.

84. Martin J, Taylor MJ, Lichtenstein P. Assessing the evidence for shared genetic risks across psychiatric disorders and traits. Psychol Med 2018; 48(11): 1759-74.

85. Fazel S, Wolf A, Larsson H, Lichtenstein P, Mallett S, Fanshawe TR. Identification of low risk of violent crime in severe mental illness with a clinical prediction tool (Oxford Mental Illness and Violence tool [OxMIV]): a derivation and validation study. Lancet Psychiatry 2017; 4(6): 461-8. 86. Whiting D, Fazel S. How accurate are suicide risk prediction models? Asking the right questions for clinical practice. Evid Based Ment Health 2019; 22(3): 125-8.

87. Dunne AL, Gilbert F, Daffern M. Elucidating the relationship between personality disorder traits and aggression using the new DSM-5 dimensional-categorical model for personality disorder. Psychol Violence 2018; 8(5): 615-29.

88. Franco S, Olfson M, Wall MM, Wang S, Hoertel N, Blanco C. Shared and specific associations of substance use disorders on adverse outcomes: a national prospective study. Drug Alcohol Depend 2019; 201: 212-9.

89. Yao S, Kuja-Halkola R, Thornton LM, Norring C, Almqvist C, D'Onofrio BM, et al. Risk of being convicted of theft and other crimes in anorexia nervosa and bulimia nervosa: a prospective cohort study in a Swedish female population. Int J Eat Disord 2017; 50(9): 1095-103.

90. ten Have M, de Graaf R, van Weeghel J, van Dorsselaer $S$. The association between common mental disorders and violence: to what extent is it influenced by prior victimization, negative life events and low levels of social support? Psychol Med 2014; 44(7): 1485-98.

91. Laursen B, Plauborg R, Ekholm O, Larsen CV, Juel K. Problem Gambling Associated with Violent and Criminal Behaviour: A Danish Population-Based Survey and Register Study. J Gamb/ Stud 2016; 32(1): 25-34.

92. Dolmén L. Criminality in different countries. Stockholm, Sweden: National Council for Crime Prevention 2001.

93. Mathers C. The global burden of disease: 2004 update: World Health Organization; 2008. 94. Witt K, Lichtenstein P, Fazel S. Improving risk assessment in schizophrenia: epidemiological investigation of criminal history factors. Br J Psychiatry 2015; 206(5): 424-30.

95. Ullrich $S$, Keers R, Coid JW. Delusions, anger, and serious violence: new findings from the MacArthur violence risk assessment study. Schizophr Bull 2014; 40(5): 1174-81. 